\title{
Application of Green Marketing in the Use of Coffee Waste as A Business Creative Industry Based on Social Enterprise
}

\author{
Benedicta Evienia Prabawanti \\ Prodi Manajemen, Fakultas Ekonomi dan Bisnis, Universitas Katolik Indonesia Atma Jaya, J1.Jend. Sudirman No. 51 Jakarta 12930 \\ e-mail: benedicta.ep@atmajaya.ac.id
}

\begin{abstract}
Coffee pulp waste is one of the most significant industrial wastes today because, in the last three years, the coffee business has increased in Indonesia, especially in urban areas. Coffee pulp waste has economic value if it can use it. This study is conducted to (1) describe the interest of coffee shops in South Jakarta to provide coffee pulp waste as cosmetic raw materials, (2) to apply green marketing as a social business strategy to develop creative industries. This research is a qualitative descriptive study with a case study approach. To discover coffee shop owners' interests to utilize coffee grounds waste, data collection through interviews with 30 coffee shop owners in South Jakarta, and observation. Determine the strategy of implementing green marketing in coffee shops through the utilization of coffee grounds waste produced. The results showed that coffee shops in South Jakarta produced 1-5 kg of coffee waste per day. All owners have not utilized the coffee grounds waste. The interview results showed the coffee shop owner's desire to provide coffee pulp waste produced for use as raw material for making cosmetics. Utilizing this coffee pulp waste can lead to new businesses that can be developed as creative industries. The new company is a social business that impacts solving social problems, namely creating new jobs in environmentally friendly cosmetics made from coffee grounds waste.
\end{abstract}

Keywords: Waste, green marketing, creative industry 


\section{INTRODUCTION}

Around the end of 1980, a new term emerged in marketing. The name knew the new time of Green marketing. Green marketing uses Environmental issues as a strategy developed to market products. The campaign about green marketing is growing and makes the business world more susceptible to getting the environment. The magnitude of the business world's concern in the background certainly makes a significant change to its running. These changes pose new challenges that must be answered by business challenges. This challenge can be seen as a challenge and also an opportunity. Eco-labeling, eco-brand, and advertising environments are Green Marketing Tool. The label will help businesses create environmentally friendly products and waste processing industries better, resulting in damage or environmental pollution.

The development of the creative industry is an important concern for the government at this time because the development of creative industries have a positive impact on other aspects that exist in the business environment, including the social, cultural, environmental, and image of the nation's identity. Besides, through the creative industries businesses can create a positive business climate, support the utilization of renewable resources, and encourage the creation of innovations. Another benefit of the creative industries is, some of the products of creative industries in the form of services and non-material forms can be distributed digitally, such as music and software, can be environmentally friendly, and can reduce distribution costs are generally quite large. The emergence of creative industries also have a social impact, the creative industries have contributed to the creation of jobs. The economic creative industry creates many jobs and professions as new promising in terms of revenue where these professions previously did not exist or were not regarded as a profession, such as a barista (music composer and arranger, to the cartoonist. Innovation and creativity are created from this industry, making this industry should receive special attention from the government. The government should be active in mentoring, supervision, and provision of venture capital so that this industry continues to grow and sustain.

Although this industry is relatively new, the creative industry is sufficient to improve the economy of Indonesian society. Given that Indonesia has a demographic bonus is a large number of productive age population. The development of this industry in Indonesia is quite a lot of potential. This is evidenced by the creativity generated by the millennial generation in creating various forms of products or services in this industry, and it boosts the Indonesian economy through innovation and creativity which generated the creative industry players.

Green marketing can be applied in all sectors, services, and works because green marketing aims to meet consumers' needs and desires to invite consumers to understand environmentally friendly consumer behavior. The coffee shop industry is a fast-growing industry in the past three years. Lots of new coffee shops have sprung up in Jakarta and several other big cities. The number of coffee shops that emerged resulted in increased production of coffee pulp waste produced. Food industry waste generated from food and beverage business owners is one of the most significant contributors to waste. If we know how to process the trash, a new industry will create, which is also profitable and will undoubtedly reduce organic waste generated from this industry. Because every industrial process always produces waste, waste processing must do from the beginning of the production process. Waste management must carry out from upstream to downstream. If this is not done, then the threat of pollution will be fatal (Xue et al., 2013; Mohanty, 2012). In particular, the food and beverage industry's production can produce liquid, concrete, or other forms of waste vulnerable to the environment. Based on this, the handling and management of industrial waste results show a very high urgency. Furthermore, education for small-scale business actors related to handling and managing business waste is crucial (Nasir \& Fatkhurohman, 2010).

Economically, there is a lot of industrial waste that can be recycled to provide economic benefits. The treatment of industrial waste refers to efforts to provide services to the waste generated by specific industries. In turn, it also has an economic impact not only for industry players but also for those who have an interest in the trash (Achillas et al., 2013). Waste 
generated by the food and beverage industry is not always in the form of rubbish or dirt that cannot reprocess modern technology. Significant effort must bring together parties who can utilize industrial waste with business actors that produce waste in their production activities. With the principles of $3 R$ (reuse, reduce and recycle), $4 R$ ( $3 R+$ replace), up to $5 R$ ( $4 R+$ replant), the supply of waste from the food and beverage industry can be re-empowered and minimize residuals.

The latest data shows that South Jakarta, specifically 200 coffee shops, are actively operating. Every processing of coffee beans into coffee grounds must produce coffee grounds. The resulting coffee grounds are usually thrown away and become waste. In contrast, in reality, coffee grounds are rich in antioxidants that can use as cosmetic ingredients, such as masks, body scrubs, bath bombs, soaps, and scrubs. Because of its unique texture, coffee grounds can also function as cleansers and shed dead skin cells (cleansers). Coffee grounds are also relatively acidic, so they are not liked by insecticides, insects, and ants. Coffee grounds are also rich in nitrogen residues so that they can apply as plant-fertilizing nutrients. Coffee grounds are also rich in primary nutrients so that they can use a mushroom planting media. The smell of aromatic coffee grounds with antibacterial, antifungal, and anti-odor effects can also apply as a refrigerator and room odor remover. The number of coffee shops that produce coffee grounds as waste in the South Jakarta area encourages research to carry out related to the utilization of coffee grounds waste as a business opportunity that can develop. The purpose of this study is (1) to describe the interest of coffee shops in South Jakarta to provide coffee grounds waste as cosmetic raw materials, (2) to apply green marketing as a social business strategy to develop creative industries.

\section{RESEARCH METHOD}

The study conduct with the research object is the owner/manager of the coffee shop in the Jakarta area. Thirty coffee shop owners in South Jakarta are respondents to this study. This research uses a qualitative approach (Neuman, 2007; Creswell, 2009), which is descriptive, using a case study approach. This study uses descriptive research methods to obtain an overview of information, explanations, and conditions related to applying green marketing applications to use coffee waste as a business that creates creative industries based on social enterprises.

The data collection method was carried out using interview techniques with coffee shop owners in DKI Jakarta. The study population was the owner of the coffee shop in DKI Jakarta. The sampling method used was non-probability sampling, using a sampling method based on criteria (Judgment / Criterion Sampling). The researcher will send a questionnaire to coffee shop owners who meet the requirements of respondents. After they received the question link and stated that they were willing to be interviewed, the researcher would go to the coffee shop owner and conduct the interview. Interviews were conducted in a structured manner, with premade instructions. Interview questions included types of coffee, use of coffee grounds, the amount of waste per day, how to provide manure to those in need, and the store's interests to work together in the future. In essence, the purpose of the interview is to get an overview of the implementation of green marketing done by the coffee shop owner if using waste coffee grounds. The collection of information is done by identifying the strengths, weaknesses, opportunities, and threats of the utilization of waste coffee grounds.

Results of subsequent interviews compiled using qualitative data that is processed in the form of a percentage. The results of each question item seen from the picture of the study's object, which is useful for the writer to determine the next steps as a follow-up to this study.

\section{RESULT AND DISCUSSION}

The results of the implementation of green marketing by using waste coffee grounds to create a creative industry results quite surprising to researchers, this is because apparently, not many people know about the benefits that are owned by the waste coffee grounds. More coffee shop owners or entrepreneurs dispose of the resulting coffee grounds. Results of interviews

Jurnal Manajemen dan Organisasi (JMO), Vol. 11 No. 3 , Desember 2020 Hal. 136-142 
indicate their wishes provide free coffee grounds to the person who will process the waste, as one example of their ignorance about the value possessed of the coffee grounds. Yet when it has been reprocessed, coffee grounds have a high enough selling value. Below is an explanation for each question on the questionnaire that was distributed to coffee shops in Jakarta.

\section{Interview Results}

The study results find that the types of coffee used in coffee shops showed that the kind of coffee that was always widely sold was Arabica Gayo Sumatra (23 percent). This bitterflavored coffee is ever sold and much loved by coffee fans (Figure 3). However, there are still many other types that are quite widely sold, such as Robusta Temanggung, Arabica Toraja, and different archipelago coffee that not mention in the answers to the questionnaire first Page Copyright Notice.

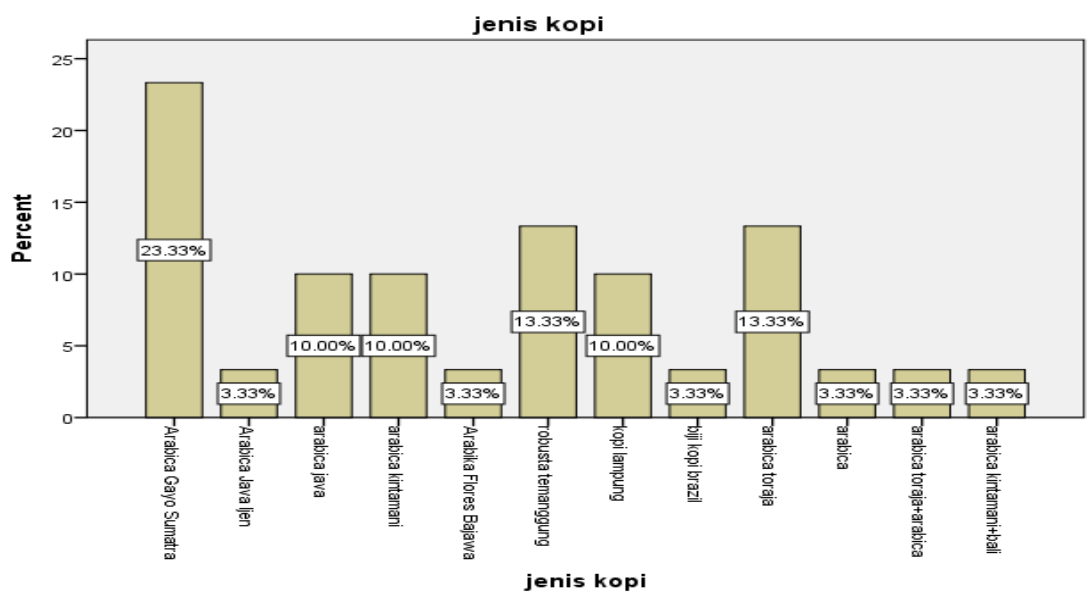

Figure 1. The variant of coffee

The consequence of a coffee shop entrepreneur is the presence of coffee waste in pulp from processed coffee beans. What is done by the businessman in responding to the considerable amount of coffee grounds waste every day? The interview results show the amount of coffee grounds waste produced by the coffee shop in 1-5 days. Variant This was stated by 67 percent of coffee shops (Figure 2). Of this considerable amount, as many as 70 percent of coffee shops admit not knowing the benefits of coffee waste (Figure 3). Instead of being wasted and harming the environment, coffee waste is given free of charge to those in need (Figure 4). A total of 30 coffee shops, 73 percent of which so far have provided free of charge to producers who need coffee grounds to be recycled. The rest sell at low prices (Figure 5).

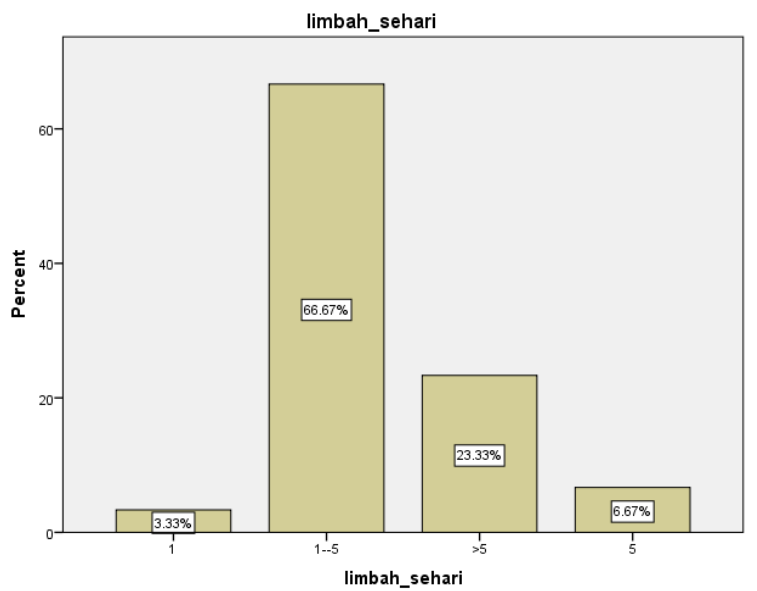




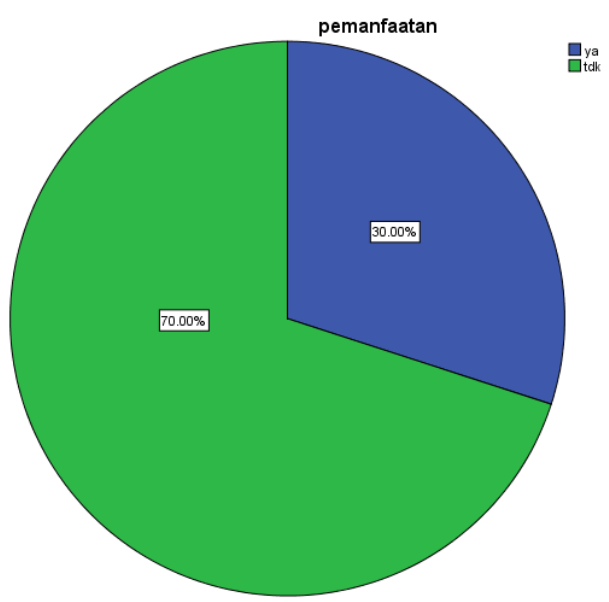

Figure 3. Knowledge of coffee dregs waste utilization

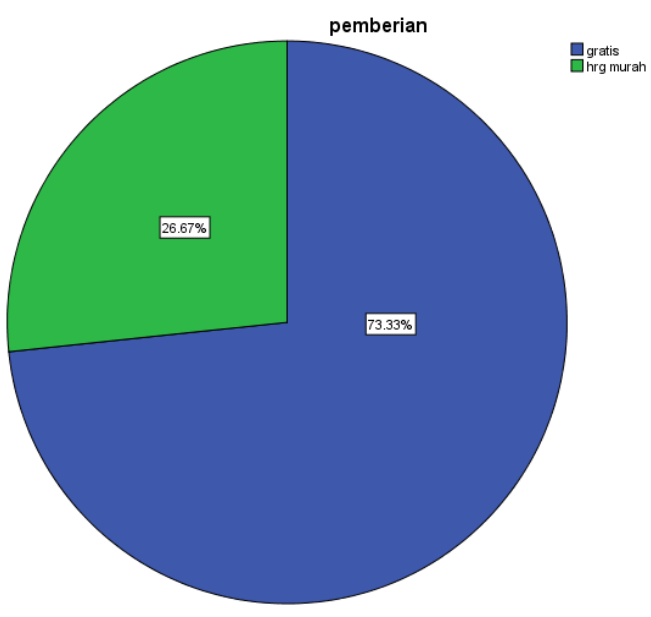

Figure 4. The desire to share coffee waste waste cheaply or free

To utilize coffee waste for economic value, almost all coffee shops owner willing to work together to collect coffee grounds (Graph 9). this study shows that as producers, they have realized that coffee waste or pulp cannot be left alone after learning that coffee grounds can be utilized and has implications for increasing revenue. All coffee shop owners admit that they are willing to benefit from coffee grounds waste to be used as cosmetics if there are parties who can provide new knowledge and skills using technology. Which party is meant to be, of course, can work together with the university or industry and other interested parties. Based on the results of interviews and observations conducted by researchers at 30 coffee shops in South Jakarta, the authors describe the use of green marketing that can be applied to the utilization of coffee waste produced by 30 coffee shops that have been interviewed.

\section{Green Marketing Application for Coffee Waste Produced by Coffee Shops}

Marketing is an essential tool that must be present in every business that is built. Through marketing, entrepreneurs can educate about the products or services produced and owned by the company. Green marketing is a form of marketing that sells products or services that are environmentally friendly and have a value of sustainability. Why is it necessary to use a green marketing strategy for coffee shop owners to use coffee waste? The answer is to invite coffee shop owners to make positive contributions that have exchange rates that affect ecological sustainability. Ecological sustainability is now an important topic that should be present in 
every company's vision and mission. Paying attention to environmental sustainability will make the business run longer and positively impact the business's environment.

Green marketing is defined as a management process that is holistically responsible for identifying, anticipating, and satisfying customer needs and profitability (companies, local communities, and governments) without damaging the natural environment and the order of human life (Mohammed \& Xavier, 2010). Strategic uses green marketing, not only about the final product. Instead, it must consider the impact of all existing processes on each production activity undertaken. A developed (produced) cannot be separated from how the product is consumed and how the work affects the environment. The opportunity to provide environmentally oriented products is a growing business opportunity today. One way to apply green marketing is to pay attention to environmental functions isolated from original strategic decisions. In this condition, the company will not avoid consumer apathy or mistrust of consumers on environmentally friendly products.

Green marketing applications must be real, come from strong environmental values, and internalize in broader business culture. The coffee shop owner must educate every employee about the utilization of coffee grounds waste. This education is essential so that any waste coffee grounds produced by the coffee shop are separated between dry and wet waste. Training also needs to be given to determine any cosmetic product that can be made by utilizing waste materials on coffee grounds.

This research tries to answer the social problems in the food and beverage industry as the giant food and beverage waste producer. This research is an implementation of social innovation by applying green marketing. Through education to the coffee shop owners and employees to take advantage of the coffee grounds waste as raw material for cosmetics or mushroom growing media. This activity may alter coffee waste worthless and of no benefit to something valuable. Through the utilization of appropriate technology, waste coffee grounds can be used as a cosmetic raw material. Social innovation is becoming part of value creation that can encourage new industries and increase society's economic activity.

\section{CONCLUSION}

The results of this research have pointed out that the businessman wanted food and drinks can minimize the waste generated by the production process of food processing and beverages they sell. Reducing waste from food and beverage waste is one of the efforts business owners can make to maintain and maintain environmental balance. One of the efforts to reduce food and beverage waste can be started by sorting waste, sorting food and beverage raw material waste by paying attention to waste sorting rules, namely reuse, reduce, and recycle. This needs to be done so that the sorted waste from food and beverage processing can be used as raw material for other products. Examples such as waste coffee grounds can be used as raw material for mushroom growing media and cosmetic raw materials.

Coffee shops are one of the major waste generators in the food and beverage industry today, due to the growing number in Jakarta and the surrounding areas. From the research results, the amount of coffee grounds produced is quite a lot. Waste coffee grounds are thrown away turned out to have an effect that is not good for the environment, one of which is the odor arising from waste coffee grounds will certainly disturb the environment, in addition to waste coffee grounds can contaminate water when waste coffee grounds discharged into a river or into stacked on the ground continuously. Therefore, education about the utilization of waste coffee grounds can be done to reduce environmental pollution. Because it turns out that coffee grounds have a lot of benefits that can be used, including as a raw material for cosmetics, as a growing medium for mushrooms, as a water filter media containing hazardous waste contaminants such as lead and mercury. With the knowledge they have about how to use coffee grounds waste, coffee shop owners can create a new business from the waste coffee grounds they produce. The activity of utilizing coffee grounds waste has a considerable impact on environmental sustainability and creates new jobs. 
A campaign about green marketing can be used by the owner of the coffee shop that is already utilizing waste coffee grounds to produce a new product, it is attracting the attention of potential consumers to be a consumer in the coffee shop who care for the environment. Green marketing campaigns have become one of the ways that can be done by the coffee shop to encourage customers to care about the environment, and it is becoming an attractive campaign at this time, given the public awareness of environmental conservation has been increasing. Besides allowing the emergence of innovations to take advantage of the coffee grounds waste as raw material for production. An innovation that appears is a form of social innovation that is part of the creation of economic activity for social entrepreneurial activity that is currently being developed in Indonesia and also in the world.

\section{REFERENCE}

Achillas, C., Moussiopoulos, N., Karagiannidis, A., Banias, G., \& Perkoulidis, G. (2013). The use of multicriteria decision analysis to tackle waste management problems: A literature review. Waste Management \& Research, 31(2), 115-129.

Creswell, J. W. (2009). Research Design (Pendekatan Kualitatif, Kuantitatif, and Mixed). Yogyakarta: Pustaka Pelajar.

Mohammed M. E. D., \& Xavier, F. (2010). The determinants of hotels' marketing managers' green marketing behavior. Journal of Sustainable Tourism, 18(2), 157-174.

Mohanty, M. (2012). New renewable energy sources, green energy development and climate change: Implications to Pacific Island countries. Management of Environmental Quality: An International Journal, 23(3), 264-274.

Nasir, M. \& Fatkhurohman. (2010). Model pembentukan kesadaran kolektif terhadap manajemen lingkungan pengusaha kecil tahu - tempe di Solo. Jakarta: Laporan Hibah Bersaing Dikti.

Neuman, W. L. (2007). Basics of Social Research Methods: Qualitative and Quantitative Approaches. 2nd Edition. Boston: Allyn and Bacon.

Xue, M. L. J., \& Xu, Z. (2013). Management strategies on the industrialization road of state-ofthe-art technologies for e-waste recycling: the case study of electrostatic separation: A review. Waste Management \& Research, 31(2), 130- 140. 